\title{
The Romanian Chemical Production Sector (SRPC): Economic Parameters and Some Recent Trends within European Context
}

\author{
IONEL BOSTAN ${ }^{*}$, COSTICA ROMAN ${ }^{1}$, COSTEL BOARIU ${ }^{2}$ \\ ${ }^{1}$ Stefan cel Mare University of Suceava, Faculty of Economics and Public Administration, 13 Universitatii Str., 720229 \\ Suceava, Romania \\ ${ }^{2}$ Gheorghe Asachi Technical University of Iasi, Faculty of Hydrotechnics, 67 Professor Dimitrie Mangeron Blvd, 700050, \\ Iasi, Romania
}

\begin{abstract}
This paper is dedicated to investigating the situation and the evolution of a traditional sector of the national economy - the Romanian Chemical Production Sector (SRPC). The authors take on macrostatistical approaches regarding the evolution of the respective sector in the recent period, given the integration of the Romanian economy into that of the European Union. In a very synthetic way, we also refer to the development of this sector, which it experienced during the centralized economy of Romania (before 1989), contrary to those that followed after 1990, as a result of erroneous decisions at the macroeconomic level. Also, using highly accurate/credible data and information (NIS, CEFIC, etc.), we outline an image of the current European chemical industry, in terms of economy and international trade - which ranks second in total world sales (by about 17\%), while the USA contributes 14\%; even though it is globally competitive, China's trade pressure is exacerbating innovation processes in this important EU sector. Finally, given that this approach also includes the indication of critical elements/difficulties, we present some proposals to improve the situation, proposals that we consider as relevant as possible.
\end{abstract}

Keywords: chemical industry; resources; production; indicators; import/export

\section{Introduction}

As this approach brings into discussion the Romanian Chemical Production Sector (SRPC), it should be mentioned that its evolution was favoured, at all stages, by the existence of resources that Romania had more than any country in this area of Europe: petroleum, natural gas and salt. However, if we take a look at the manner in which things have been carried out over a longer period of time, we will have to notice a considerable decline in the respective sector. Thus, it should be noted that if until the early 1990s, SRPC was really a catalyst for the development of the national economy, today it is experiencing a clear setback. Essentially, we are talking about the fact that "it has a marked deficit, the number of plants and employees has decreased drastically and the production is 11 times lower" [1].

The specialized literature provides explanations as credible as possible, ranging from the ones relating to international circumstances to the concrete macro- and micro-economic/managerial Romanian ones [2-4], regarding the contraction of the SRPC production, the disappearance of some sub-branches (the production of artificial and synthetic chemical fibres, of plastics and synthetic rubber), the massive reduction of the personnel in the sector in question, etc. It is righteously stated that "in Romania the production of synthetic rubber, synthetic fibre, polystyrene, polyethylene, pesticides, has disappeared and the local market has thus become a prisoner of imports" [5].

Causes such as "the lack of a national strategy regarding the privatisation of the chemical industry; the lack of transfer of technology in recent years and the use of energy-consuming technologies..., are often recognised; throughout time there was also a lack of a successful Romanian entrepreneurship, which in the meantime was created. Instead, some of the plants were sold to buyers who were only looking to close them. At the same time, privatisations were delayed, with the effect of discouraging professional investors" [1].

*email: ionel_bostan@yahoo.com 
Obviously, for all these, all the issues arising from environmental or economic [6-8] restrictions, which emerged after Romania's integration into the European Union, must be taken into account.

According to the authors of this paper, the following sections are intended to ensure a better understanding of the issues related to the SRPC, especially with regard to certain economic parameters and recent trends revealed within European and global context.

\section{Materials and methods}

This approach, mainly from a statistical perspective, but also from that of the implications induced at the economic level, highlights the concrete changes that have occurred in the sector submitted to our observations. To do this, our analysis operates with highly credible data and information, gathered by the authors following a thorough bibliographic documentation - specialized literature, reports of prestigious profile institutions, economic press, etc.

As it will be seen, the authors rely on the selection and processing of data and information made available by institutions whose fundamental concerns are the elaboration of reports aimed to accurately inform stakeholders and the general public: the European Chemical Industry Council (CEFIC), the Landscape of the European Chemical Industry, the National Institute of Statistics (Romania), the Department of Foreign Trade and International Relations within the Ministry of Economy (Government of Romania), the European Commission - Strengthening Strategic Value Chains for a future-ready EU Industry - report of the Strategic Forum for Important Projects of Common European Interest (2019), the European Agency for Chemical Products (ECHA), the European Environment Agency and COFACE - Sectorial study on the chemical industry in Romania 2013.

We also consider some studies and research published under the auspices of the Technical Sciences Academy of Romania (ASTR) and the General Association of Romanian Engineers (AGIR), focused on the topic of industrialization and deindustrialization of the national economy.

In order to reach the conclusions of this paper, we use, to a considerable extent, methods such as analysis, comparison, logical deduction, etc. We emphasize the fact that for the elaboration of this paper, we have mainly considered highly accurate and reliable recent data (the last five years). Also, while making assessments regarding the perspectives of the field addressed, we rely on the studies and reports elaborated by consecrated profile specialists and worldwide renowned institutions.

\section{Results and discussions}

\subsection{Landmarks on SRPC during the centralized management of the national economy}

In 1989, SRPC made goods worth approx. €35 billion (updating today), respectively 221 times more than in 1950; the average annual growth rate tended to $15 \%$ [9].

Between 1960 and 1989, the number of companies included in the SRPC increased from 57 to 89, and the average number of employees increased from 45,900 in 1960 to 207,000 in 1989. However, the peak of the evolution of the SRPC was the year 1980. At that time, the economic entities were harmoniously distributed throughout the national territory (Figure 1), and the resources available to Romania (oil, natural gas, salt, etc.) were capitalized on. 


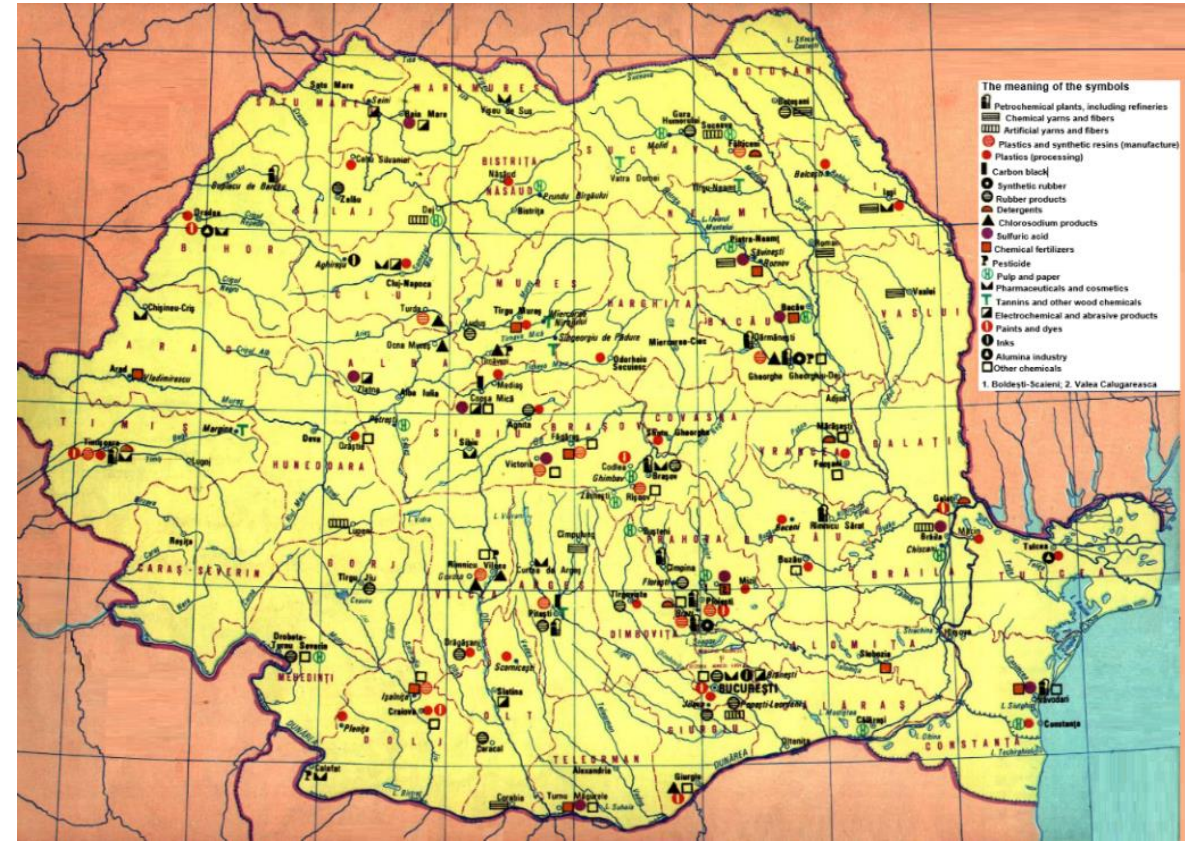

Figure 1. Map of the Romanian chemical industry (1980s)

Source: http://posturi.files.wordpress.com/2012/10/12-harta-industria_chimica1980.jpg

The country's capital owned $14.6 \%$ of chemical production, followed by Argeş County - the petrochemical sector, where "Arpechim Refinery" accounted for $8 \%$ of national chemical production, with refineries in Prahova holding a share of 7.2\%. At the Borzesti and AMURCO Petrochemical Plant (Bacau) there was a share of $6.7 \%$, la Vâlcea (Oltchim), a share of $6.5 \%$ was recorded, and Brasov County had a share of $6.1 \%$ of chemical production [10].

Bringing very accurate information, a relatively recent paper published under the coordination of Professor Gh. Ivănuş [11] includes comprehensive analyzes of the situation and evolution SRPC (1989-2016), proposing at the same time several reindustrialization solutions. They envisage new stages of development in organic and inorganic chemistry, on the line of synthetic yarns and fibers, plastics and catalysts, chemical fertilizers, but also drugs and biotechnologies, etc.

A large space is given to oil refineries, petrochemical and chemical units in operation until 1989, but also to the concrete situation in which they were during the transition economy, some being dismantled and sold as scrap metal (Figure 2).

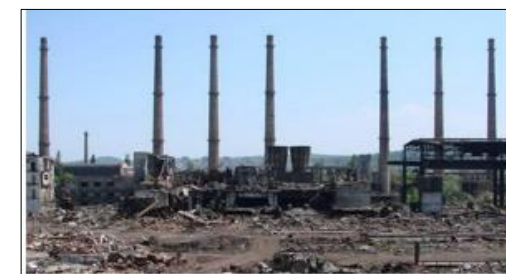

a. Victoria

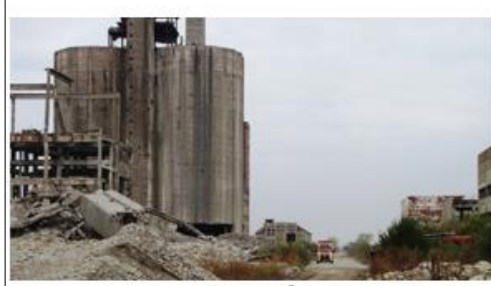

c. Arad

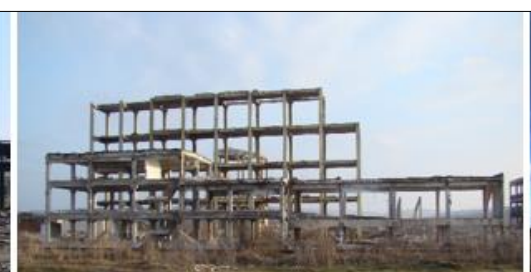

b. Târnăveni

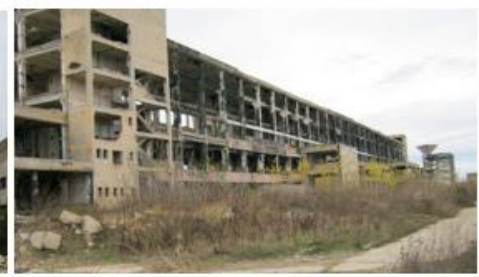

d. Giurgiu

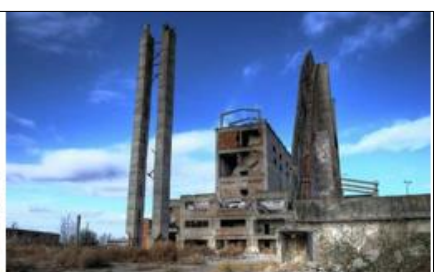

c. Vladimirești

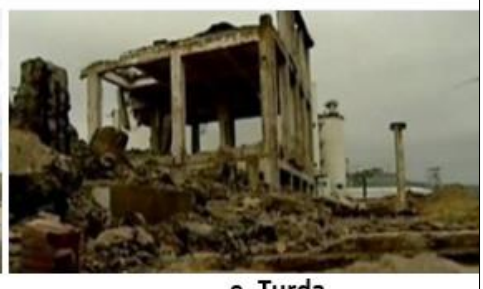

e. Turda

Figure 2. The status of belonging entities SRPC during the transition economy Source: Compilations made by the authors after images on https://www.e-ziare.ro/ 
In this sense, Professors Frangopol and Ivănuş reveal that "(...) after 2000, Romania exported 50 million tons of scrap metal, ie the equivalent of about 1000 oil refineries the size of the Arpechim Refinery in Pitesti, with a processing capacity of 3.5 million tons / year of oil" [12]. The same authors claim that in 2018 there were only 17 petrochemical units in operation, because in the period 19902017102 units were demolished and 13 units were closed. Thus, the oil processing capacity decreased by approx. 2.5 times, in 2018 compared to 1990 (from about 35 million tons / year, to 13.7 million tons / year).

Some of the possible solutions, advanced by Professors Frangopol and Ivănuș [12], for revitalization SRPC:

- boosting the research-development activity in the field of basic organic and inorganic chemistry, allocating more important resources, given that it is a "top" field, in which there is also experience and special achievements; in this context, engineers must play a special role [13];

- reindustrialization of the national sector "oil-petrochemistry-chemistry", by restarting the petrochemical system in Pitești;

- in the field of synthetic fibers - it is necessary to recycle polyester fiber waste.

The explanation: the resumption of fiber production of this type in the medium term is almost impossible, because the related manufacturing units of basic raw materials have been demolished.

\subsection{The Chemical Industry in the European Union}

Certainly, the SRPC cannot remain outside the concerns of the Romanian macro-decision maker, as long as the European Union, which Romania is a part of, has "the role of world leader in many sectors", including the chemical industry [14].

It is important to note that "the European Union aims to ensure that by 2020, chemicals will be produced and used in such a way as to minimize any significant adverse effect on human health and the environment. An EU strategy for a non-toxic environment is under development, which favours innovation and development in the field of sustainable substitutes, including non-chemical options" [15].

Even if, over the last period, the EU chemical industry has diminished its market share [4], a number of 30,000 companies are currently active in this field, with a turnover of $€ 565$ billion [16]. Moreover, it is very important that 1,171,000 direct employees are found in the same sector. For comparison, according to the same sources, Romania owns 979 companies in this field, with 22,500 employees and a turnover adding up to $€ 2.3$ billion.

Customer sectors of the EU chemicals industry are represented graphically (Figure 3) as follows:

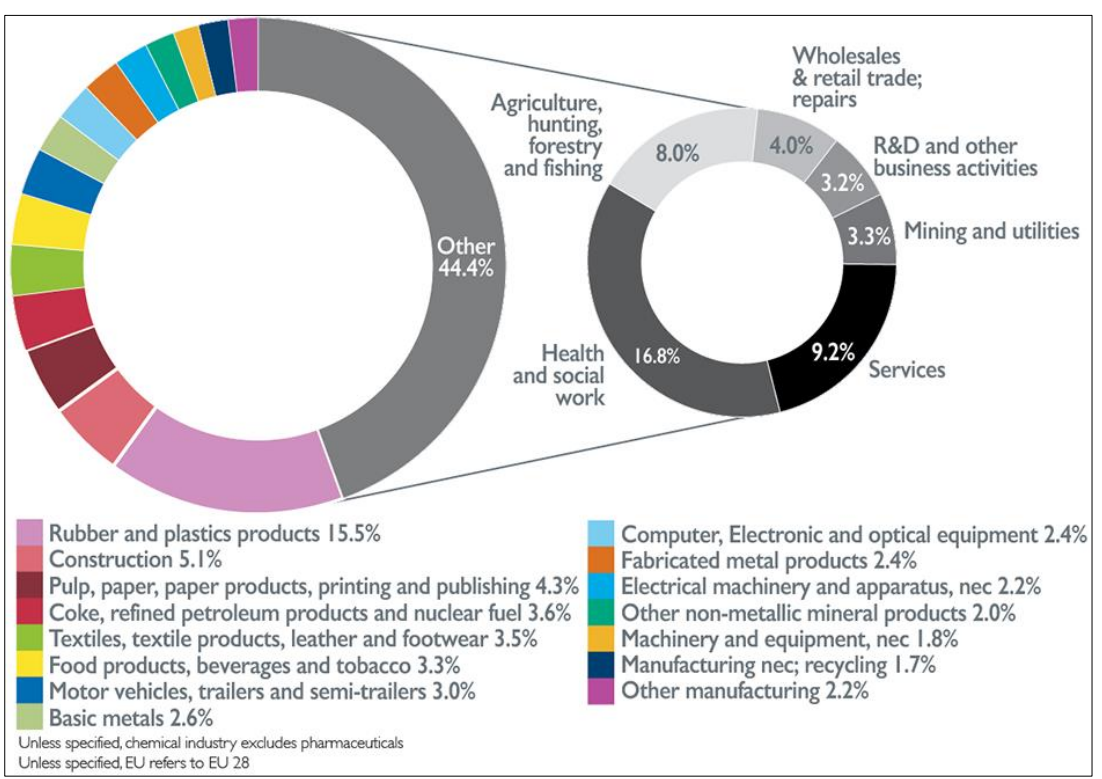

Figure 3. Customer sectors of the EU chemicals industry [17] 
However, beyond the performances of the sector in question, certain causes have led to a decrease in EU chemical production in the first half of 2019 (Figure 4), and the exports and domestic sales have remained relatively constant.

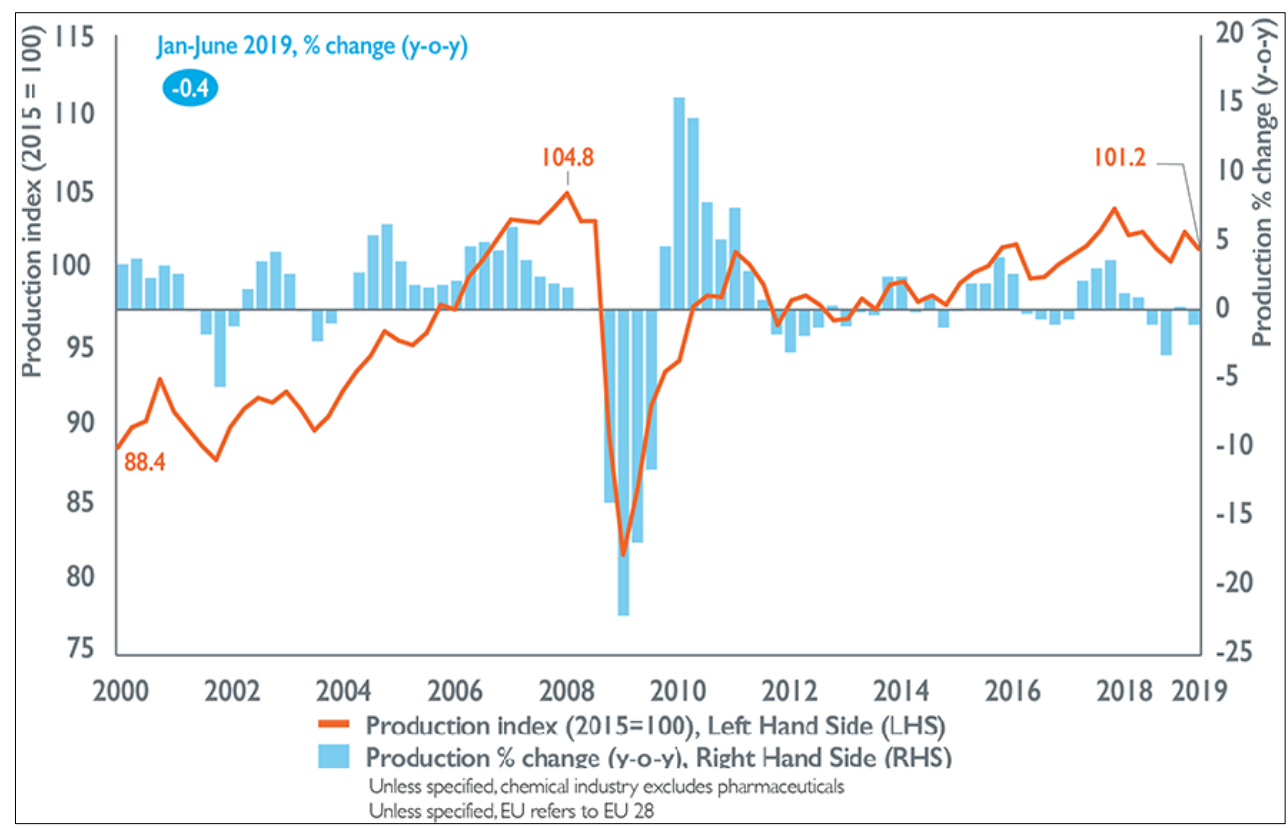

Figure 4. EU chemical industry production [18]

Amongst the causes of this kind, the following are notable: the rules adopted by certain states from different parts of the world, the manifestation of protectionism, the crisis of other industrial sectors that use products of the analysed sector, but also "the uncertainty related to Brexit and the escalation of the trade wars between the USA and its key partners, which diminish the investor's confidence" [18].

However, it is estimated that in the future, the EU will experience sustainable growth of the chemical industry, based on innovation and material diversification. In fact, the EU remains a net exporter of chemicals. We mention that, in 2018, there was a significant surplus of non-EU net trade, amounting to $€ 48.1$ billion.

\subsection{The recent evolution of the Romanian Chemical Production Sector (SRPC)}

At a national level, after the abandonment of the centralized economic system, the SRPC underwent appreciable changes, both quantitatively and qualitatively. The situation is related, to a considerable extent, to the delay in the restructuring, on economic/competitive bases, of the petroleum refining sector, which had previously experienced an excessive development (during the period of centralized economy the refining capacity was at a double level as compared to the quantity of extracted petroleum). Later it was noted that "the gradual liberalization of prices, interests and of the exchange rate revealed the lack of competitiveness of many products and the non-viability of some enterprises" [19].

Governmental measures such as the cancellation of debts, financing and refinancing from public budgetary resources, etc. caused the debts/losses to finally affect the SRPC. The privatisation of the profile companies could not be an efficient solution, even if this was the very objective targeted by the macro-decision maker. Then, the fact that the activities of this sector are predominantly energyconsuming, through the liberalization of energy prices, the SRPC has come to present no important competitive advantages.

Analyses carried out in the previous years, in order to reveal the comparative advantages/ disadvantages and those manifested in the field of competitiveness on the EU markets, taking into account the SRPC data, indicate an unfavourable situation for Romania (Table 1). 
Table 1. SRPC - comparative advantages on the EU markets* [20]

\begin{tabular}{|c|c|c|c|}
\hline Sub-group & $\begin{array}{c}\text { Comparative } \\
\text { advantage }\end{array}$ & Trend & Observations \\
\hline $\begin{array}{l}\text { Chemical industry prod- } \\
\text { ucts }\end{array}$ & $\begin{array}{l}\text { Comparative } \\
\text { disadvantages }\end{array}$ & & \\
\hline $\begin{array}{l}\text { - fertilizers } \\
\text { - other inorganic chemical } \\
\text { products }\end{array}$ & \multirow{2}{*}{$\begin{array}{l}\text { Significant com- } \\
\text { parative and } \\
\text { competitive ad- } \\
\text { vantage }\end{array}$} & & \multirow[t]{2}{*}{$\begin{array}{l}\text { Reduced unit value } \\
\text { as compared to the } \\
E U \text { average }\end{array}$} \\
\hline $\begin{array}{l}\text { - vinyl chloride polymers } \\
\text { - plastics waste }\end{array}$ & & & \\
\hline $\begin{array}{l}\text { - medicinal and pharma- } \\
\text { ceutical products }\end{array}$ & & $\begin{array}{l}\text { Exports share } \\
\text { increase }\end{array}$ & $\begin{array}{l}\text { Increase of the unit } \\
\text { value towards the } \\
\text { EU average }\end{array}$ \\
\hline $\begin{array}{l}\text { - plastics in non-primary } \\
\text { forms }\end{array}$ & & $\begin{array}{l}\text { Low exports } \\
\text { share (growing } \\
\text { deficit) }\end{array}$ & \\
\hline
\end{tabular}

Although we have important domestic raw material resources, the chemical industry has been segmented, generating internal value chains of the interrupted type [20]. Moreover, we cannot get round the fact that due to the corporate policy of the assets owned by the multinational companies, the cooperation between Romanian companies has become as unpredictable as possible [21]. These, but also other reasons related to the international situation or to the Romanian macro- and microeconomic/managerial framework, have led to modest performances of the sector targeted by our study.

For example, the data in Table 2 are as eloquent as possible regarding the Romania's international trade (January - November 2019) with chemical industry products (goods by sections in the standard international trade classification - CSCI Rev. 4).

Table 2. International trade in chemical industry goods [22]

\begin{tabular}{|c|c|c|c|c|c|}
\hline \multirow{3}{*}{\begin{tabular}{|l|} 
\\
Cod CSCIRev. \\
SITC Rev. 4 \\
\end{tabular}} & \multirow{3}{*}{ Sections } & & & \multicolumn{2}{|c|}{ - lei million - } \\
\hline & & \multicolumn{2}{|c|}{ November } & \multirow{2}{*}{$\begin{array}{c}1 . I .-30 . X I . \\
2018 \\
\end{array}$} & \multirow{2}{*}{$\begin{array}{c}1 \text { 1.I.-30.XI. } \\
2019 \\
\end{array}$} \\
\hline & & 2018 & 2019 & & \\
\hline \multirow{3}{*}{5} & FOB Exports & & & & \\
\hline & Chemicals and similar products not elsewhere specified & 1184,1 & 1264,0 & 12738,3 & 13881,2 \\
\hline & CIF Imports & & & & \\
\hline \multirow[t]{2}{*}{5} & Chemicals and similar products not elsewhere specified & 4306,8 & 4645,3 & 44830,0 & 50048,2 \\
\hline & Trade Balance FOB/CIF & & & & \\
\hline 5 & Chemicals and similar products not elsewhere specified & $-3122,7$ & $-3381,3$ & $-32091,7$ & $-36167,0$ \\
\hline
\end{tabular}

As it can be clearly seen, the balance of international trade operations FOB/CIF with goods made in the SRPC - 1.I.-30.XI.2019 is a negative one (-36 167.0 million lei). Regarding the number of employees employed in the SRPC and the net average earnings, in 2019, they reached the following values (Table 3 and 4):

Table 3. Number of employees in SRPC [22]

\begin{tabular}{|c|c|c|c|c|c|c|c|c|c|c|c|c|c|}
\hline & & & & & & & & & & & \multicolumn{3}{|c|}{ thousand persons - } \\
\hline \multicolumn{14}{|c|}{ Number of employees on } \\
\hline & 31.XII. & 31.I. & 28.1I. & 31.III. & 30.IV. & 31.V. & 30.VI. & 31.VII. & 31.VIII. & 30.IX. & 31.X. & $30 . \mathrm{XI}$. & 31.XII. \\
\hline & 2018 & 2019 & 2019 & 2019 & 2019 & 2019 & 2019 & 2019 & 2019 & 2019 & 2019 & 2019 & 2019 \\
\hline $\begin{array}{l}\text { Manufacture of chemicals and } \\
\text { chemical products }\end{array}$ & 24,9 & 25,0 & 24,7 & 24,8 & 24,7 & 24,7 & 24,7 & 25,0 & 25,2 & 25,5 & 25,5 & 25,5 & 25,3 \\
\hline
\end{tabular}

Table 4. Average net earnings in SRPC [22]

\begin{tabular}{|c|c|c|c|c|c|c|c|c|c|c|c|c|c|}
\hline & & & & & & & & & & & & & - lei - \\
\hline & 2018 & & & & & & 201 & & & & & & \\
\hline & Dec & Jan & Feb & Mar & Apr & May & June & July & Aug & Sep & Oct & Nov & Dec \\
\hline $\begin{array}{l}\text { Manufacture of chemicals and } \\
\text { chemical products }\end{array}$ & 3454 & 2874 & 2800 & 3105 & 3157 & 3218 & 3390 & 3094 & 3084 & 3049 & 3024 & 3163 & 3546 \\
\hline
\end{tabular}


In 2018, the distribution of enterprises per activities of the national economy, as reported by the National Institute of Statistics (2019), showed that the number of enterprises specialized in the manufacture of chemicals and chemical products was of 885 , and the number of employees within them was of 21394 persons [19].

The turnover for the enterprises whose main activity was in the field of the manufacturing of chemicals and chemical products (Table 5, 2015-2018), was as follows:

Table 5. Turnover for enterprises having a main activity in SRPC [23]

\begin{tabular}{|lrrrr|}
\hline & \multicolumn{5}{c|}{ lei million current prices } \\
\hline $\begin{array}{l}\text { Activity } \\
\text { (CANE Rev. 2 divisions) }\end{array}$ & $\mathbf{2 0 1 5}$ & $\mathbf{2 0 1 6}$ & $\mathbf{2 0 1 7}$ & $\mathbf{2 0 1 8}$ \\
\hline $\begin{array}{l}\text { Manufacture of chemicals } \\
\text { and chemical products }\end{array}$ & 10322 & 10255 & 11308 & 12415 \\
\hline \hline
\end{tabular}

Referring back to the issue of Romania's international trade with chemical industry products, we insist on their value position in relation to the total import/export operations, which can be illustrated with the help of Figure 5.

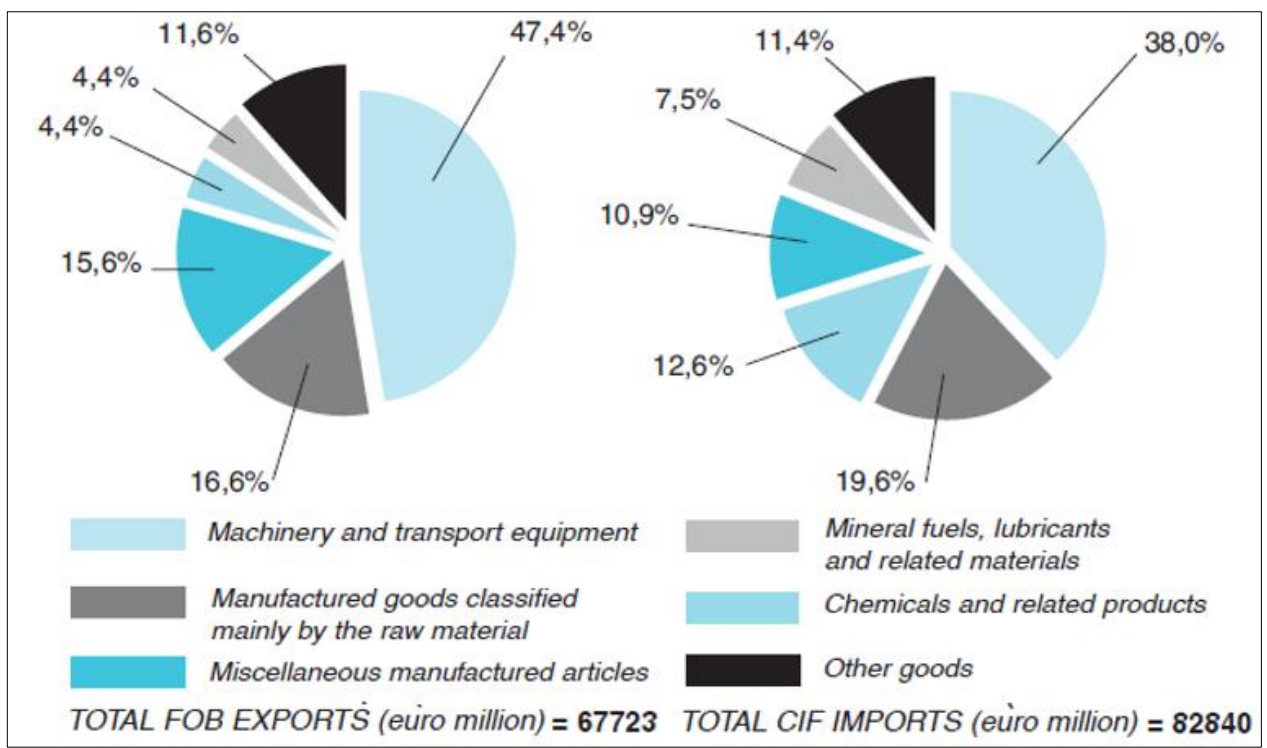

Figure 5. International trade in goods of Romania, by main sections according to SITC, Rev. 4, in 2018 [23]

As it can be clearly seen, the statistical data presented hereof reveal clear non-performances characterizing the activity of the SRPC. The solutions can only come from the direction of modern refurbishment of the national chemical industry: "In the short term, the reindustrialization of the petroleum-petrochemical sector means the restart of the operations in Piteşti, in an integrated system, respectively of the Arpechim and Oltchim Râmnicu Vâlcea units; nowadays, for the chemical industry, Romania has raw materials - salt, petroleum, natural gas - which will contribute to a reindustrialization according to the modern technology and the economic principles that govern the world economy" [17].

Obviously, it is necessary for them to be accompanied by governmental policies determining fiscal stability and predictability, encouraging scientific research and specialized education - at all levels, innovative initiatives, etc. 


\section{Conclusions}

Our work on the SRPC, from the perspective of the recently registered economic parameters, allows us to point out the existence of relatively unfavourable results. The most illustrative finding is that, even if Romania has the natural resources needed to supply the analysed sector, for long periods of time the chemical industry fails to address the needs of the national economy when it comes to goods form this sector. In terms of the balance of international trade, the value of the chemical products imported by Romania exceeds by far that of exports $(€ 1.51$ billion $=$ deficit in 2018 ; $€ 0.75$ billion $=$ deficit for the first 11 months of 2019). Moreover, apart from the low competitiveness, the indicators are low in terms of the number of enterprises or employees within the SRPC, but also in terms of remuneration of the human resources involved in this sector, etc. On the other hand, it is estimated that in the future, the EU will experience sustainable growth of the chemical industry, based on innovation and material diversification. In fact, the EU remains a net exporter of chemicals (significant surplus of non-EU net trade $=€ 48.1$ billion). Therefore, for the economic consolidation of the SRPC we consider that a new strategic approach of the Romanian macro-decision maker is required, that will take into account the induction of some mutations, from the legislative ones and those concerning the training/improvement of human resources, the extension of the partnership in relation to the supply of this industrial branch, to the granting of new attributions to the sectoral committee related to the field of chemistry and petro-chemistry. The country's desire to "become a net exporter of chemicals and petrochemicals again" certainly involves massive government support, but also the involvement of the financial-banking system in this direction, which comes with credit and guarantee instruments.

Obviously, all of these must be subsumed to a new vision on the sector in question, which should consider as a priority the repositioning of the innovation and quality components, carefully following the expansion of the market shares of the SRPC. And a first urgency in this regard is the elaboration of a national strategic document, focused on concrete objectives and actions, which will determine, in a reasonable time horizon, the increase of the production of chemical fertilizers, synthetic rubber, synthetic yarns and fibers and pharmaceutical goods.

\section{References}

1. DEACU E., Radiografia industriei chimice româneşti: de la avanpostul modernizării ţării la dispariţie, Adevarul.Ro/Economie, July 19. 2017. Available at:

https://adevarul.ro/economie/afaceri/radiografia-industriei-chimice-romanesti-avanpostulmodernizariitarii-disparitie-1_596efb425ab6550cb847139f/index.html/.

2. CHIVU L., CIUTACU C., GEORGESCU G., Descompunerea și recompunerea structurilor industriale din România. Direcții de strategie, Institutul Național de Cercetări Economice "Costin C. Kirițescu", Bucharest, 2016. Available at:

https://www.piarom.ro/wp-content/uploads/2016/11/Industria-2016-FINAL-3-oct-corectat-

FINAL.pdf?x39362/.

3. POPESCU C.R., Dezindustrializare, reindustrializare și dezvoltare regională, Meteor Press, Bucharest, 2003.

4. ***COFACE, Studiu sectorial privind industria chimică din România, Bucharest, 2013. Available at: http://www.coface.ro/Stiri-Publicatii/Stiri/Industria-chimica-din-Romania-unul-dintre-principalelemotoare-de-redresare-economica/.

5. CIRIPERU D., Reindustrializarea României. Chimia, industria cu cel mai mare deficit comercial din economie: 4 mld. euro în 2016, Ziarul Financiar, June 26. 2017. Available at:

https://www.zf.ro/companii/reindustrializarea-romaniei-chimia-industria-cu-cel-mai-mare-deficitcomercial-din-economie-4-mld-euro-in-2016-16516012/.

6. BOSTAN I., BURCIU A., CONDREA P., Trends of the communitarian cohesion policies and advertising for eco-investments, Environ Eng Manag J, 2010, 9(6):847-851. 
7. MATES D., GROSU V., HLACIUC E., BOSTAN I., BUNGET O., DOMIL A., MORARU M., ARTENE, A., Biological assets and the agricultural products in the context of the implementation of the IAS 41: A case study of the Romanian agro-food system, Arch. Biol. Sci., 2015, 67, 705-714. DOI:http://dx.doi.org/10.20961/jab.v19i2.449.

8. BOSTAN I., GROSU V., The social effects of the current economic crisis on the European Union labour market. Revista de Cercetare şi Intervenţie Socială, 2010, 31, 7-21.

9. ***COMISIA NAŢIONALĂ PENTRU STATISTICĂ, Anuarul statistic al României pentru anul 1990, București, 1991.

10. MOCANU A., Cum poate renaște industria chimică din România, Newsweek.ro, February 28. 2020. Available at: https://newsweek.ro/economie/cum-poate-renaste-industria-chimica-din-romania/.

11. IVANUS GH. (Coord.), Pagini din istoria dezvoltării industriei României. Industria chimică, petrochimică și de petrol. Editura AGIR, Seria Repere istorice, București, 2016, pages: 378.

12. FRANGOPOL P.T., IVANUS GH. Redezvoltarea industriei chimice româneşti, Academica, No. 5-6, 2018, Anul XXVIII (331-332), pp. 28-35. Available at: https://acad.ro/academica2002/ rev2018/pag_acad2018_nr331_332_mai_iun.pdf/.

13. JINESCU V.V., Discursuri și expuneri academice, Editura AGIR, Bucuresti, 2017, pages: 360.

14. *** COMISIA EUROPEANA, Politica industrială: recomandări pentru sprijinirea poziţiei de lider a Europei în șase domenii strategice de activitate, Bruxelles, November 5. 2019. Available at: https://ec.europa.eu/romania/news/20191105_europa_lider_sase_domenii_activitate_ro/.

15. *** COMISIA EUROPEANĂ, Evaluarea din 2019 a punerii în aplicare a politicilor de mediu ale UE. Raport de țară - Romania, Bruxelles, April 4. 2019, SWD(2019) 130 final. Available at:

https://ec.europa.eu/environment/eir/pdf/report_ro_ro.pdf/.

16.CEFIC, Landscape of the European Chemical Industry, 2020. Available at: https://www. chemlandscape.cefic.org/.

17. *** ICCA, Report 2019, Catalyzing Growth and Addressing Our World's Sustainability Chalenges (Oxford Economics). Available at:

https://www.chemlandscape.cefic.org/wp-content/uploads/2016/09/Graph_EU28_1_V3-

1024x875.png/.

18.***CEFIC CHEMDATA INTERNAȚIONAL, 2019. Available at: https://www.chemlandscape. cefic.org/wp-content/uploads/2019/11/Graph_EU28_2-1024x845.png/.

19. DOCHIA A., Despre soarta tristă a industriei chimice româneşti, Ziarul financiar, October 10. 2012. Available at:

https://www.zf.ro/opinii/despre-soarta-trista-a-industriei-chimice-romanesti-10183496Lupica/. 20. ***GUVERNUL ROMANIEI, Strategia naţională de export a României pentru perioada 20142020 (HG no. 395/2014). Available at: http://legislatie.just.ro/Public/DetaliiDocumentAfis/159039/.

21. VASIESCU A., FRANGOPOL P.T., 90\% din industria chimică a României a fost distrusă după 1989, Bursa, March 22. 2018. Available at:

https://www.bursa.ro/petre-t-frangopol-academia-romana-90-procente-din-industria-chimica-aromaniei-a-fost-distrusa-dupa-1989-27223431/.

22.***NATIONAL INSTITUTE OF STATISTICS, 2020, Economic and social evolution of Romania during 1.I-31.XII.2019. Available at:

http://www.insse.ro/cms/sites/default/files/field/publicatii/buletin_statistic_lunar_nr12_2019.pdf/ 23. ANDREI T. (Coord.), Romanian Statistical Yearbook - 2018, National Institute of Statistics, Bucharest, 2019. Available at: https://www.insse.ro/en/tags/romanian-statistical-yearbook/.

$\overline{\text { Manuscript received: } 14.03 .2019}$ 